Omni-Akuatika, 14 (2) : 79-85, 2018
ISSN: 1858-3873 print / 2476-9347 online
Research Article
journal homepage: http://ojs.omniaquatika.net

\title{
The Biodiversity of Gastropods In Karapyak Rocky Shores, Pangandaran Region, West
} Java Province, Indonesia

\author{
Asep Sahidin $^{1,2 \star}$, Zahidah ${ }^{2}$, Herman Hamdani ${ }^{2}$, Indah Riyantini ${ }^{3}$, Roni Sewiko ${ }^{4}$ \\ ${ }^{1}$ Laboratory of Aquatic Resources, Faculty of Fisheries and Marine Sciences, Universitas Padjadjaran \\ ${ }^{2}$ Department of Fisheries, Faculty of Fisheries and Marine Sciences, Universitas Padjadjaran \\ ${ }^{3}$ Department of Marine Science, Faculty of Fisheries and Marine Sciences, Universitas Padjadjaran \\ ${ }^{4}$ Department of Marine Technology, Pangandaran Marine and Fisheries Polytechnic
}

"Correspondance author: syahid1104@gmail.com

\begin{abstract}
Pangandaran rocky shores have a unique ecosystem and a variant of invertebrate organisms such as mollusk from the gastropod class. This study aims to analyze the biodiversity of gastropods on the rocky shore of Karapyak beach. This research consists of 5 stations. The quadrant set by $1 \mathrm{~m} \times 1 \mathrm{~m}$ vertically toward the sea. The result found 773 individuals scattered in nine families. The family of Neritidae dominated $(43 \%)$, followed by family cyprinoids with $6.3 \%$. Nerita plicata is a species found to dominate in every station with an average abundance $(256 \pm 10) \mathrm{and} / \mathrm{m}^{2}$. Using the Bray-Curtis cluster analysis, showed variations in the distribution and abundance of different gastropods vertically into the ocean and uniformly distributed horizontally to the shore. Substrate and tidal are the main variables in the spatial distribution of gastropods in the Karapyak beach.
\end{abstract}

Keywords: Pangandaran, Karapyak, rocky shores, gastropod

\section{Introduction}

Coastal zone is an ecosystem (towards land and sea) which there are a complex interaction both physical, chemical, biological, socio-economic and cultural factors. These are resulting complex problems and require a holistic solution. Coastal and marine areas in Indonesia have an important role in providing natural resources and environmental services that considerably have potential values. Coastal and marine areas are the location of several unique, interrelated, dynamic and productive ecosystems. Muliawan et al. (2016) stated that the coastal area generally functioned as a source of nutrients for biota and also for its residence, feeding ground, nursery ground, and spawning ground. One spot in coastal areas that have rich biodiversity is the intertidal zone (Hutomo and Moosa, 2005; Datta et al., 2010; Ruttenberg and Granek 2011; Hamza et al., 2018).

The intertidal zone is the smallest spot of world oceans, which are only a few meters between high and low tides. Although the area is very limited, it has the largest variety of environmental factors compared to other oceans (Petovic et al. 2017). This area has a greater variety of lives than those found in larger subtidal regions (Nybakken, 1992). This zone is mostly populated by organisms and has a great diversity both for animals and plants (Nybakken, 1992). One of them is gastropods from mollusk phyla. Gastropods have developed into the largest, diverse group of mollusks and one of the world's major organisms. Gastropods that occupy most habitats have evolved into groups of plankton eaters and grazers (Manohara et al, 2011).

Gastropods are the class of the most successful mollusks and have a widespread, ranging from land, fresh water, intertidal and into the deep sea (Nybakken 1992). Not much research on Gastropoda is done in the intertidal zone at Pangandaran coastal area, especially about the diversity of organisms that occupy the intertidal zone. High human 
activities in utilizing the waters area can lead to the degradation of aquatic environment quality which can affect the ecosystem (Kari, 2002; Zahedi, 2008).

Pangandaran is a small peninsula on the southern coast of West Java, Indonesia. Pangandaran has a craggy beach type with narrow ravines, sloping northern slopes with Pananjung bay in the east and Parigi in the sandy west. This area belongs to an intertidal, the coastal zone that experiences shallow tides of sea water and gets sufficient light penetration. In this zone, there is an abundance of organisms that are associated with coral reefs, seagrass, mangroves, sand and coral reefs.

Anthropogenic pressures in Coastal Pangandaran resulted in the degradation of aquatic biota biodiversity. The scarcity of some species must be anticipated because it will result in the extinction of the biota. In addition to these, Pangandaran has problems due to lack of data. Based on these reasons, it is necessary to conduct a research on spatial and temporal variations of marine invertebrate biota as an effort to conserve biodiversity in Pangandaran Coast.

\section{Reaearch Methods}

The study was conducted at Karapyak rocky shores, Pangandaran. Samples were taken 5 times during the period from July to November 2017 from 5 stations (Figure 1). Identification of gastropods organisms in Aquatic Resource Laboratory at Fisheries and Marine Science Faculty, Padjadjaran University.

The sampling of gastropods organisms is done by the quadratic transect method placed at the observation station with purposive sampling. Quadratic transects are rectangular-sized $1 \times 1 \mathrm{~m}^{2}$ of 5 transects each station which is then divided into small quadrans with the size of each $20 \times 20 \mathrm{~cm}^{2}$. Gastropod samples were taken from five small portions of randomly selected transects (Fachrul 2007).

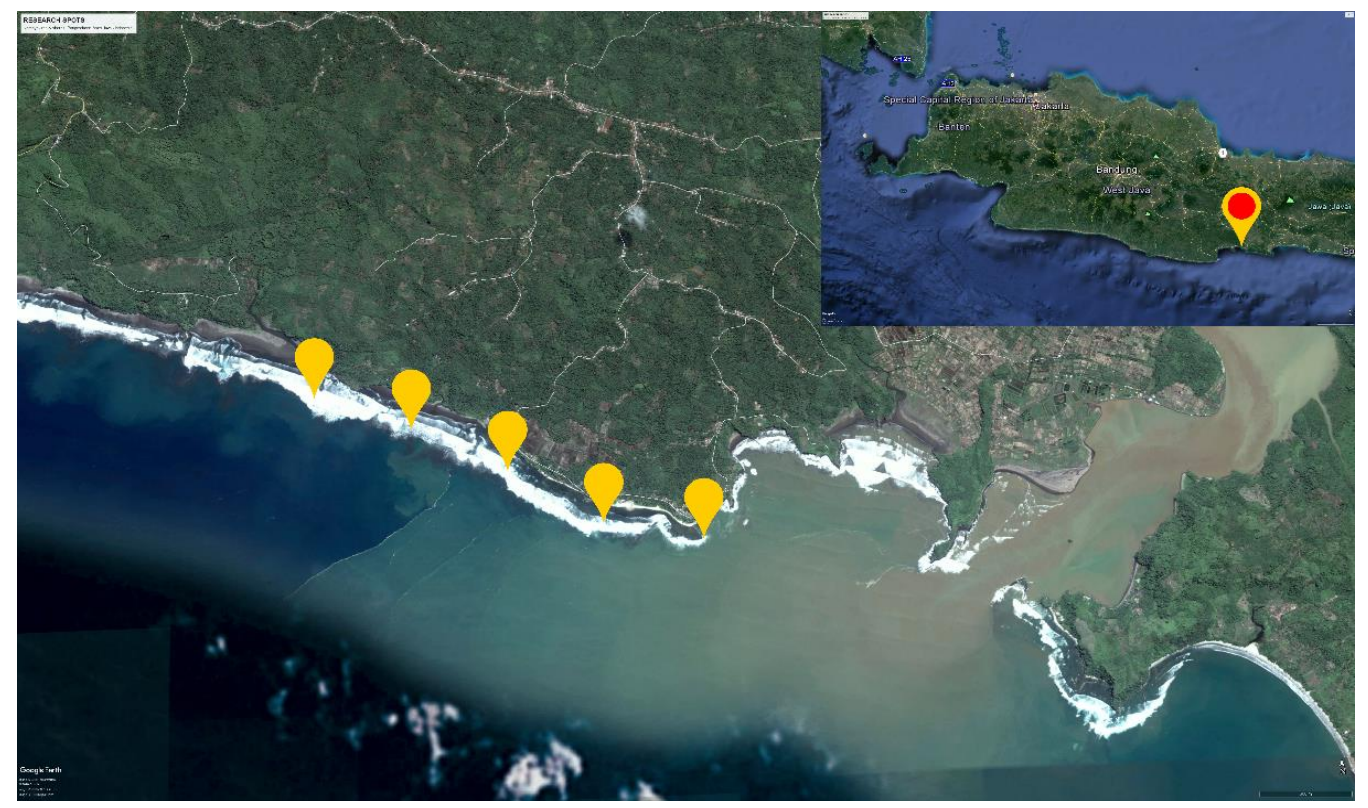

Figure 1. Sampling locations

Gastropods are identified to the genus level by looking at the morphology of the body, with the help of the identification book of Water Invertebrates (Fauchald 1977, Dharma 2005) and the writing of the nomenclature following the World Register of Marine Species (WoRMS: http://www.marinespecies.org/index. php). The measurement of physical and chemical parameters of sampling sites are presented in Table 1. 
Table 1. Parameters and tools

\begin{tabular}{llll}
\hline Parameters & Units & Tools & Location \\
\hline Temperature & ${ }^{\circ} \mathrm{C}$ & Thermometer & Insitu \\
Turbidity & $\mathrm{cm}$ & Secchi disk & Insitu \\
\hline $\mathrm{DO}$ & $\mathrm{mg} / \mathrm{L}$ & DO meter & Insitu \\
$\mathrm{pH}$ & - & $\mathrm{pH}$ meter & Insitu \\
Salinity & $\mathrm{ppt}$ & Refractometer & Insitu \\
\hline Gastropods & $\mathrm{Ind} / \mathrm{m}^{2}$ & Quadrant & in-situ and Laboratorium \\
\hline
\end{tabular}

The data of the Gastropoda community processed by using the density $(\mathrm{K})$ and the Shannon index $\left(\mathrm{H}^{\prime}\right)$ (Clarke and Warwick, 2001), with the following formula:

Macrozoobenthos abundance $(K)$

$$
K=\frac{10.000 x n_{i}}{\mathrm{~A}}
$$

with: $K=$ Macrozoobentos abundance (ind $/ \mathrm{m}^{2}$ ), $n_{i}$ $=$ total macrozoobentos founded (ind), $\mathrm{A}=$ Tools aperture $\left(\mathrm{cm}^{2}\right)$ dan 10.000 is a constant (convertion from $\mathrm{cm}^{2}$ to $\mathrm{m}^{2}$ ).

Diversity index with Shannon indexs $\left(H^{\prime}\right)$ (shannon, 1948; Sarma and Das, 2004)

$$
H^{\prime}=-\sum_{i=1}^{S}\left(p_{i} x \log _{2} p_{i}\right), \text { dimana } p_{i}=\frac{n_{i}}{N}
$$

with: $H^{\prime}=$ Diversity Index, $S=$ the number of species in the community, $P_{i}=$ ratio between total species- $i$ with total individuals in the community, $n_{i}=$ total individual species $-I$ and $N=$ total individuals in the community.

Multivariate data analysis similarity Bray Curtis was used to know the distribution of gastropods groups (Brower et al., 1990) by using MINITAB v15.1.2-EQUINOX.

\section{Result and Discussion}

Composition and the density of gastropods is one of community structures characteristics that can be used to identify the distribution of aquatic biota. Based on the results, founded 773 gastropods clustered to 9 families and 12 species (Tabel 2).

Table 2. Gastropods founded on each station

\begin{tabular}{lccccc}
\hline Species & St1 & St2 & St3 & St4 & St5 \\
\hline Cerithyum muscarum & $\sqrt{ }$ & $\sqrt{ }$ & & & \\
Monetaria mauritiana & & $\sqrt{ }$ & & $\sqrt{ }$ & \\
Patella vulgata & $\sqrt{ }$ & $\sqrt{ }$ & $\sqrt{ }$ & $\sqrt{ }$ & $\sqrt{ }$ \\
Monetaria annulus & $\sqrt{ }$ & $\sqrt{ }$ & $\sqrt{ }$ & $\sqrt{ }$ & $\sqrt{ }$ \\
Nerita plicata & $\sqrt{ }$ & $\sqrt{ }$ & $\sqrt{ }$ & $\sqrt{ }$ & $\sqrt{ }$ \\
Acanthina punctulata & & $\sqrt{ }$ & $\sqrt{ }$ & $\sqrt{ }$ & \\
Turbo moluccensis & & $\sqrt{ }$ & $\sqrt{ }$ & $\sqrt{ }$ & $\sqrt{ }$ \\
Cerithyum obtusa & & $\sqrt{ }$ & & $\sqrt{ }$ & $\sqrt{ }$ \\
Erronea cylindrica & & $\sqrt{ }$ & $\sqrt{ }$ & & $\sqrt{ }$ \\
Trochus niloticus linn. & $\sqrt{ }$ & $\sqrt{ }$ & $\sqrt{ }$ & $\sqrt{ }$ & $\sqrt{ }$ \\
$\quad$ Littorinam pantherina & & & $\sqrt{ }$
\end{tabular}

The most numerous species found in station 2 (9 species), and the lowest found in station 1 (5 species). That differences caused by textures, reef compositions, and different current patterns. Sediment affected the density and species richness of macroinvertebrates (Lizarralde \& Pittaluga 2010; Sahidin et al., 2014), included gastropods from mollusk phyla (Jordas and Damodaran 2009). 


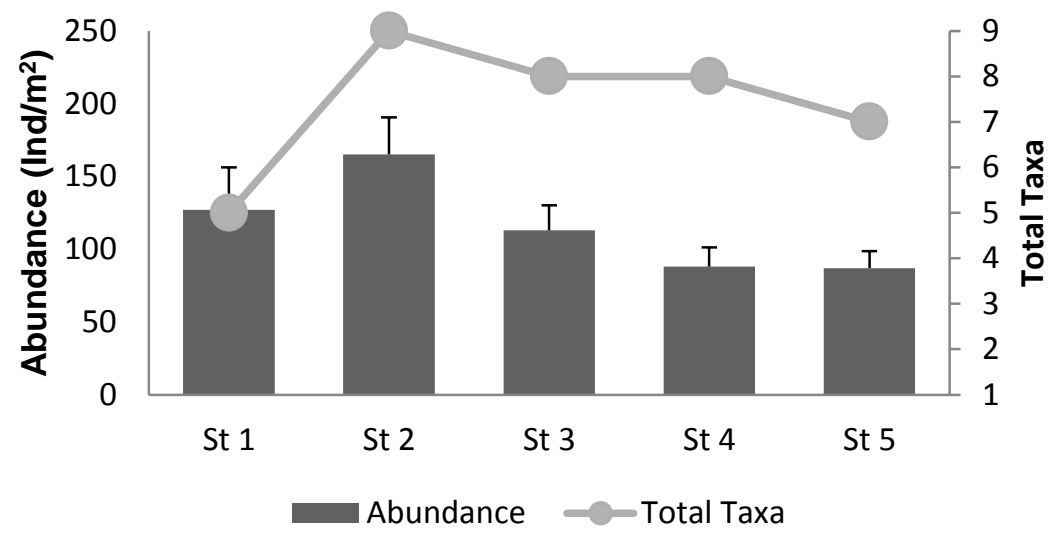

Figure 2. Gastropods Abundance and Taxa (St1=stastion 1 and $\mathrm{St} 2=$ stastion 2 in west Karapyak Coast, St3=center Karapyak Coast, St4=stastion 4 and St $5=$ station 5 in east Karapyak Coast).

Gastropods distribution showed in certain habitats, a certain area, and certain time. The lowest density founded at station 4 and 5 (Figure 2). It's a rocky-sandy beach and has faster currents than the other stations. Low density on these stations caused by the absence of substrate for gastropods to attach (Hamza et al., 2018). The embedded site is useful to withstand continuous wave action that can move substrate particles.

The lowest abundance found in stations 3 and 4 with a range of $\mathrm{H}^{\prime}=2.35$ 2.63. It can be categorized into medium diversity. The low diversity in stations 3 and 4 because the station is located in the tourist center of Karapyak Beach, so the activity of tourists will decrease the number of gastropods. According to Barbour et al., (1987) the index value of diversity can range from 0-7, with criteria: 0-2 low), 2-3 (medium), and $>3$ (high). The contamination and biota captured by tourists can be the cause of this low diversity. (Zahedi, 2008; Sirinthuwanich et al., 2017). tourist waste will have an impact on the abundance and diversity of benthic communities like gastropods (Wardiatno et al., 2017; Sahidin et al., 2018).

The highest diversity was found in stations 1 and 2 with values of $3.21-3.54$. Its station can be categorized into high diversity. This area is located east of Karapyak Beach that is rarely visited by tourists, so its ecosystem is relatively undisturbed. In accordance with the results from Zahedi's (2008) research, tourists have a negative impact on the coastal environment including the lives of aquatic biota in the region.

The highest abundance can be found in species Nerita plicata (family Neritidae) with average abundance $258 \pm 10 \mathrm{ind} / \mathrm{m}^{2}$ and Cerithyum sp (family Cerotidae) $113 \pm 15$ ind $/ \mathrm{m}^{2}$ (Figure 2). Neritidae is active and able to adapt to dynamic current conditions because it can attach to the stone to avoid the interferences from outside both the current and the predator (Darma, 2005). 


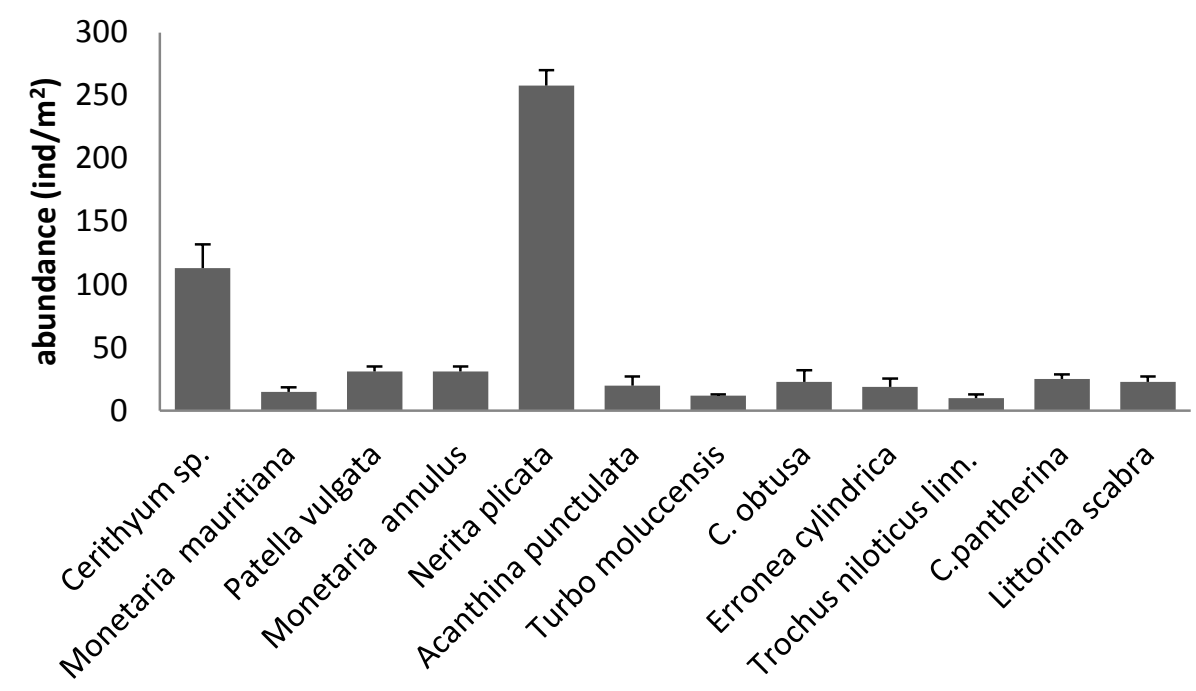

Figure 3. The abundance of gastropods from each species

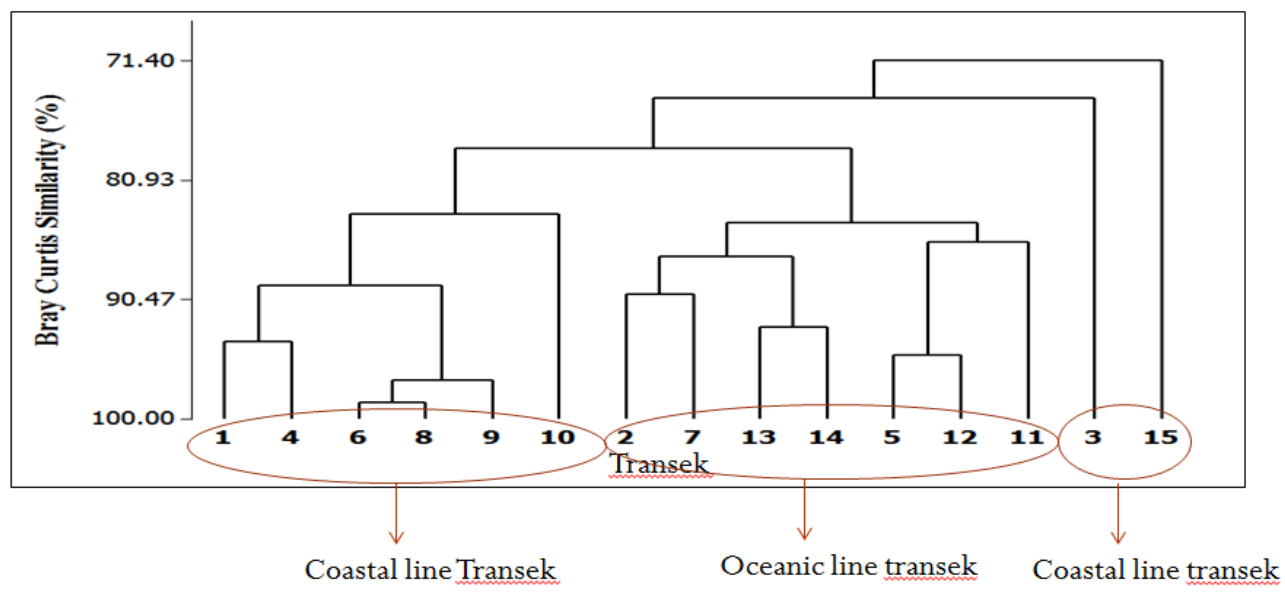

Figure 4. Gastropods spatial distribution in Karapyak Beach

Nerita plicata, Monetaria annulus, and Patella pulgata dominated founded in all stations. Mikkelsen (2011) concluded this types of gastropods are kind of mollusk which has a habit to settle in one area and colonize. Bray Curtis (Figure 4) similarity analysis showed the variation of spatial distribution based on zonation. Gastropods species and abundance similarities founded between transects on each station which horizontally toward the beach. It happened because the characteristics of water qualities parameters and the currents were relatively similar. Gastropods founded at beach zones are gastropods that are sleek and embedded in the rocks/reefs. The gastropods found perpendicular to the coast have significant differences both abundance and the species found. Gastropods found in the marine zone are dominated by active gastropods such as genus nerita and turbo. In accordance to Lizarralde and Pitulung (2010) studies that the distribution of gastropods is influenced by the current strength and substrate differences. 
Table 3. Water quality parameters

\begin{tabular}{llllll}
\hline \multirow{2}{*}{ Parameters } & \multirow{2}{*}{ Units } & \multicolumn{3}{c}{ Stations } & \multirow{2}{*}{ Standards $^{*}$} \\
\cline { 3 - 5 } & & \multicolumn{1}{c}{1} & \multicolumn{1}{c}{2} & \multicolumn{1}{c}{3} & \\
\hline Temperature & ${ }^{0} \mathrm{C}$ & $29,7-30,6$ & $30,0-30,7$ & $30,1-31,8$ & $28-32$ \\
$\mathrm{pH}$ & - & $8,1-8,3$ & $8,1-8,3$ & $7,1-8,5$ & $7,0-8,5$ \\
Salinity & $\%$ & $28,5-30,2$ & $27,5-30,1$ & $12,2-30,3$ & - \\
DO & $\mathrm{mg} / \mathrm{l}$ & $6,5-8,3$ & $6,3-8,9$ & $6,5-10,6$ & $>5$ \\
\hline
\end{tabular}

*Ministry of Indonesian Environment and Forestry number 51 (2004)

The results of water quality measurement in the sites (Table 3), when compared with the water quality standards from the Ministry of Indonesian Environment and Forestry (MKLH) (2004) on water quality standards for marine biota, indicates that the temperature, $\mathrm{pH}$, and salinity are still within the supporting range for marine life (Table 3).

\section{Conclusion}

Nerita plicata with high abundance $(256 \pm 10) \mathrm{Ind} / \mathrm{m}^{2}$ is the most dominant species founded on each station. BrayCurtis cluster analysis showed the different spatial distribution between gastropods observed perpendicular to the shore, but almost similar when observed horizontally in the shoreline. Substrates and tides were the key parameters that affected the gastropods spatial distribution at Karapyak Coastal.

\section{Acknowledgment}

Thanks to the Rector of Padjadjaran University for the Lecturers Research Internal grants scheme 2017.

\section{References}

Brower J, Zar J, Ende CV, Kane K. 1990. Field and laboratory methods for general ecology. Brown Publishers, America.

Fachrul MF. 2007. Metode Sampling Bioekologi. Jakarta: Bumi Aksara.).

Clarke K, Warwick R. 2001. Change in Marine Communities: An Approach to Statistical Analysis and
Interpretation. 2nd ed. United Kingdom: Primer-E Ltd.

Datta SN, Chakraborty SK, Jaiswar AK, Ziauddin G. 2010. A Comparative study on intertidal fauna biodiversity of selectes beaches of Mumbai Coast. Journal of environmental biology, 31(6): 981-986.

Dharma, B. 2005. Recent \& fossil Indonesian shells. Hockenheim, Germany: Conch Books.

Fauchald, K. 1977. The polychaete worms: Definition and keys to other, families and genera. Nature History Museum of Los Angeles Country. California.

Hamza W, Hameli SA, Ramadan G, Hameli MA. 2018. Coastal alternation and its impact on diversity of macrobenthic fauna in the intertidal zone of Abu Dhabi Western Coast (UAE). Journal of marine biologi \& Oceanography, 7(1): 1-11.

Hutomo M, Moosa MK. 2005. Indonesian Marine and coastal biodiversity: present status. Indian journal of marine sciences, 34(1): 88-97.

Jordas TV, Damodaran R. 2009. Infauna macrobenthos along the shelf water of west coast of India, Arabia Sea. Indian Journal Marine Science 38: 191-204.

Kari E. 2002. Soft-sediment benthic biodiversity on the continental shelf in relation to environmental variability. Marine Ecology Program Series 232: 15-27.

Lizarralde Z, Pittaluga S. 2010. Distribution and temporal variation of the benthic 
fauna in the tidal flat of the Rio Gallegos Estuary, Patagonia, Argentina. Thalassa, An International Journal of Marine Sciences 27: 9-20.

Manoharan J, Varadharajan D, Thilagavathi B, Priyadharsini S. 2011. Biodiversity and abundance of benthos along the South East Coast of India. Advances in Applied Science Research 2: 554562.

Mikkelsen PM. 2011. Speciation in modern marine Bivalves (Mollusca: Bivalvia): Insights from the published record. American Malacological Society 29: 217-245.

Ministry of Indonesian Environment and Forestry (MKLH). 2004. regulation of environment minister number 51 about seawater quality standards for marine biota. Indonesian Document.

Muliawan R, Dewinyanti I, Karina S. 2016. Struktur Komunitas Makrozoobenthos Dan Kondisi Substrat Pada Kawasan Mangrove Di Pesisir Pulau Weh. Jurnal IImiah Mahasiswa Kelautan dan Perikanan Unsyiah, Vol 1. No 2 : 297-306.

Nybakken JW., 1992. Marine Biology: an ecological approach [Biologi Laut, Suatu Pendekatan Ekologis]. Translated by: M. Eidman, D. G. Bengen, Koesoebiono, M. Hutomo dan Sukristijono, pp. 363-375, PT Gramedia, Jakarta).

Nybakken JW., Bertness MD. 2005. Marine Biology: An Ecological Approach. $3^{\text {rd }}$ edition. New York: Pearson Benjamin Cummings.

Petovic S, Gvozdenovic S, Ikica Z. 2017. An annotated checklist of the marine molluscs of the south Adriatic sea (Montenegro) and a comparison with those of Neighbouring area. Turkist Journal of Fisheries and Aquatic Science. 17: 921-934.
Ruttenberg BI, EF Granek. 2011. Bridging the marine terrestrial disconnect to improve marine coastal zone science and management. Marine ecology progress series, 434(1): 203-212.

Sahidin A, Isdradjad S, Yusli W. 2014. Macrozoobentos Community Structures of Tangerang Castal Water, Banten. Depik, 3(3): 226-233.

Sahidin A, Zahidah, Herawati H, Wardiatno Y, Setyobudiandi I. 2018. Macrozoobenthos as bioindicator of ecological status in Tanjung Pasir Coastal, Tangerang District, Banten Province, Indonesia. Biodiversitas, 19(3): 1123-1129.

Sarma P, Das D. 2004. Application of Shannon's index to study diversity with reference to cansus data of Assam.

Shannon CE. (1948). A mathematical theory of communication. The Bell System Technical Journal, 27: 379423.

Sirinthuwanich K, Sangpradub N and Hanjavanit. 2017. Impact of antrophogenic disturbance on benthic makroinvertebrate assemblages in the Phong River, Northeastern, Thailand. AACI Bioflux, 10(2): 421-434.

Wardiatno Y, Qonita Y, Mursalin, Zulmi R, Effendi $H$, Krisanti M,Mashar A, Hariyadi S, Hakim AA, Sahidin A, Widigdo B,Nursiyamah S. 2017. Determining ecological status of two coastalwaters in Western Java using macrozoobenthic community: A comparison between North Part and South Part. IOP Conf Ser: Earth Environ Sci 54 (1): 01207

Zahedi S. 2008. Turism Impact on Coastal Environmental. WIT Transactions on The Built Environment (Environmental problem in Coastal Region). 99(7): 45-57. 